BRAVZULIAN JOURNAL

OF MEDICAL AND BIOLOGICAL RESH.ARCH

www.bjournal.com.br
ISSN 0100-879X

Volume 44 (6) 497-605 June 2011

BIOMEDICAL SCIENCES

AND

CLINICAL INVESTIGATION

Braz J Med Biol Res, June 2011, Volume 44(6) 562-572

doi: 10.1590/S0100-879X2011007500056

Sildenafil decreases rat tracheal hyperresponsiveness to

carbachol and changes canonical transient receptor

potential gene expression after antigen challenge

C.T. Sousa, T.S. Brito, F.J.B. Lima, R.J.B. de Siqueira, P.J.C. Magalhães, A.A.M. Lima, A.A. Santos and A. Havt

The Brazilian Journal of Medical and Biological Research is partially financed by

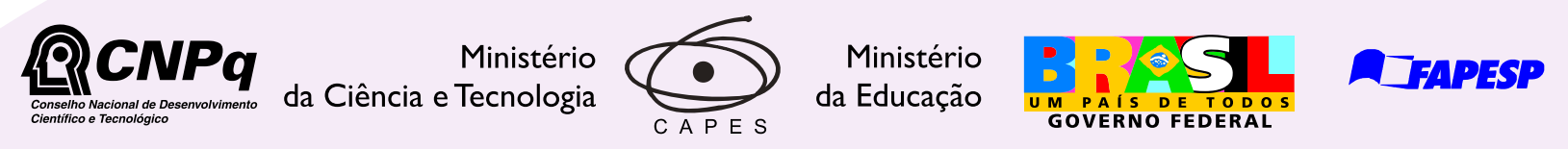

Institutional Sponsors
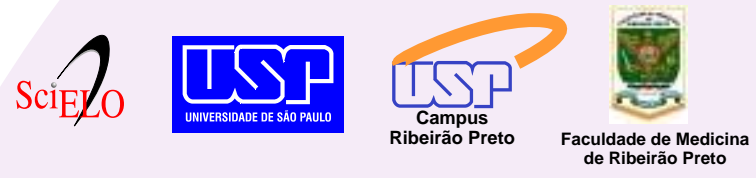

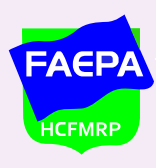

Ф SHIMADZU

GE Healthcare
Hotsite of proteomics metabolomics developped by:

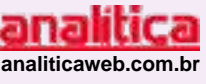

Thermo SCIENTIFIC 


\title{
Sildenafil decreases rat tracheal hyperresponsiveness to carbachol and changes canonical transient receptor potential gene expression after antigen challenge
}

\author{
C.T. Sousa, T.S. Brito, F.J.B. Lima, R.J.B. de Siqueira, P.J.C. Magalhães, \\ A.A.M. Lima, A.A. Santos and A. Havt \\ Departamento de Fisiologia e Farmacologia, Faculdade de Medicina, \\ Universidade Federal do Ceará, Fortaleza, CE, Brasil
}

\begin{abstract}
Inhibition of type- 5 phosphodiesterase by sildenafil decreases capacitative $\mathrm{Ca}^{2+}$ entry mediated by transient receptor potential proteins (TRPs) in the pulmonary artery. These families of channels, especially the canonical TRP (TRPC) subfamily, may be involved in the development of bronchial hyperresponsiveness, a hallmark of asthma. In the present study, we evaluated i) the effects of sildenafil on tracheal rings of rats subjected to antigen challenge, ii) whether the extent of TRPC gene expression may be modified by antigen challenge, and iii) whether inhibition of type-5 phosphodiesterase (PDE5) may alter TRPC gene expression after antigen challenge. Sildenafil $(0.1 \mu \mathrm{M}$ to $0.6 \mathrm{mM})$ fully relaxed carbachol-induced contractions in isolated tracheal rings prepared from naive male Wistar rats $(250-300 \mathrm{~g})$ by activating the NO-cGMP-K ${ }^{+}$channel pathway. Rats sensitized to antigen by intraperitoneal injections of ovalbumin were subjected to antigen challenge by ovalbumin inhalation, and their tracheal rings were used to study the effects of sildenafil, which more effectively inhibited contractions induced by either carbachol (10 $\mu \mathrm{M})$ or extracellular $\mathrm{Ca}^{2+}$ restoration after thapsigargin $(1 \mu \mathrm{M})$ treatment. Antigen challenge increased the expression of the TRPC1 and TRPC4 genes but not the expression of the TRPC5 and TRPC6 genes. Applied before the antigen challenge, sildenafil increased the gene expression, which was evaluated by RT-PCR, of TRPC1 and TRPC6, decreased TRPC5 expression, and was inert against TRPC4. Thus, we conclude that PDE5 is involved in the development of an airway hyperresponsive phenotype in rats after antigen challenge by altering TRPC gene expression.
\end{abstract}

Key words: Asthma; Ovalbumin; Capacitative $\mathrm{Ca}^{2+}$ entry; Transient receptor potential proteins

\section{Introduction}

Sildenafil $\left(\right.$ Viagra $\left.^{\circledR}\right)$ is a selective inhibitor of the cyclic guanosine monophosphate (cGMP)-specific type-5 phosphodiesterase (PDE5) and is useful in the treatment of erectile dysfunction and pulmonary arterial hypertension $(1,2)$. By decreasing capacitative $\mathrm{Ca}^{2+}$ entry through a change in transient receptor potential (TRP) gene expression, sildenafil inhibits human pulmonary vascular remodeling, which is involved in the sustained increase of pulmonary arterial pressure $(3,4)$.

TRP channels were first described in studies of light perception by Drosophila melanogaster, involving rhodop- sin coupling to phospholipase $\mathrm{C}$ and activation of channels responsible for sustained $\mathrm{Ca}^{2+}$ influx (i.e., store-operated $\mathrm{Ca}^{2+}$ channels) (5). Research has concentrated on proteins of the canonical TRP (TRPC) subfamily, and much evidence suggests that they are a part of store-operated $\mathrm{Ca}^{2+}$ channels in many cells (6-8). Such channels are regulated by the filling status of intracellular $\mathrm{Ca}^{2+}$ stores and, once depleted by either $\mathrm{Ca}^{2+}$ release from the sarcoplasmic reticulum or inhibition of adenosine triphosphate-driven sarcoplasmic/endoplasmic reticulum $\mathrm{Ca}^{2+}(\mathrm{SERCA})$ pumps, subsequent $\mathrm{Ca}^{2+}$ entry from extracellular compartments may be promoted (9).

Correspondence: P.J.C. Magalhães, R. Cel. Nunes de Melo, 1127, 60430-270 Fortaleza, CE, Brasil. Fax: +55-85-3366-8333.

E-mail: pjcmagal@ufc.br

Received December 15, 2010. Accepted April 14, 2011. Available online May 2, 2011. Published June 13, 2011. 
In airway smooth muscle, the control of intracellular $\mathrm{Ca}^{2+}$ levels is involved in several functions, including contraction and cell proliferation, adhesion, and survival (10). Acute and chronic allergic conditions, such as those that occur in asthma, change the intracellular dynamics of cytoplasmic $\mathrm{Ca}^{2+}$, promoting several events that culminate in reversible airflow limitation and a loss of lung function (11). Asthma is an inflammatory disease that especially affects small airways and is often associated with airway hyperresponsiveness to contractile agents and damage to the epithelial layer, which exerts a protective role on sensory nerves and smooth muscle from inhaled irritants and releases epithelium-derived relaxing factors under physiological conditions (12).

The inflammatory environment generated by allergic responses modifies $\mathrm{Ca}^{2+}$ signal transduction pathways, leading to a phenotype of bronchial hyperresponsiveness with the potential involvement of proteins that belong to the TRPC subfamily in such a phenomenon (13). Increased intracellular cGMP levels caused by PDE5 inhibition elicit various cellular events, such as airway smooth muscle relaxation and inhibition of cellular inflammation or immune responses. The present in vitro study was designed to answer the following three questions: $i$ ) is sildenafil able to reduce tracheal hyperresponsiveness to a contractile agent after an antigen challenge?; ii) can TRPC gene expression be changed by antigen challenge?, and iii) can inhibition of PDE5 alter TRPC gene expression?

\section{Material and Methods}

\section{Animals}

Male Wistar rats (250-300 g) were housed under standard conditions with free access to food and water in the Central Housing Facility of our institution. Animal welfare and the experimental procedures were conducted in accordance with the Ethical Principles for Care and Use of Laboratory Animals published by the Brazilian Society for Laboratory Animal Science (http://www.cobea.org.br; accessed February 4,2011 ), with a project license approved by the Animal Ethics Committee of our institution (protocol \#41/06).

\section{Active sensitization to ovalbumin}

Rats were actively sensitized to ovalbumin (OVA; $10 \mathrm{mg} /$ $\mathrm{kg}$ ) on days 1,3 , and 5 by an intraperitoneal (ip) injection of chicken egg albumin (grade II; Sigma, USA) diluted in $0.9 \%$ sodium chloride. The OVA solution was injected (1 $\mathrm{mL} / \mathrm{kg}$, once per day) directly into the peritoneum, with care taken not to damage the internal organs. Control animals received saline under similar conditions. The animals were used 21 to 50 days after sensitization. The success of the antigen sensitization procedure was confirmed by means of Schultz-Dale reactions $(14,15)$ performed on tracheal rings of all rats that were previously sensitized to OVA, which were the same as used in the tracheal responsiveness studies.
Briefly, when a contraction occurred as a consequence of the direct OVA addition to the bath chamber, sensitization was considered to be positive.

\section{Antigen challenge}

Ovalbumin-sensitized animals were exposed to nebulized solutions of OVA in a single 30-min session that was divided into two periods without interruption (first with 1 $\mathrm{mg} / \mathrm{mL}$ and then with $5 \mathrm{mg} / \mathrm{mL}$ for 15 min each) generated by an ultrasonic nebulizer (RespiraMax, NS Indústria de Aparelhos Médicos, Brazil). Rats were sacrificed $12 \mathrm{~h}$ later with an ip injection of chloral hydrate $(400 \mathrm{mg} / \mathrm{kg})$ to evaluate tracheal contractility in vitro. Control rats were sensitized to saline inhalation.

\section{Tracheal tissue set-up and experimental protocols}

Although the hyperresponsiveness observed in asthma occurs mainly in bronchial segments (16), in the present study we evaluated airway smooth muscle reactivity using isolated tracheal rings. The trachea was dissected and placed on a dish containing physiological salt solution, $\mathrm{pH}$ 7.4 , to remove adhering fat and connective tissue. Next, the trachea was cut transversely into cylindrical rings (with 3-4 cartilage rings), which were suspended in a heated jacket. The rings were superfused with warmed $\left(37^{\circ} \mathrm{C}\right)$ and gassed $\left(5 \% \mathrm{CO}_{2}\right.$ in $\left.\mathrm{O}_{2}\right)$ in Krebs-Henseleit solution: $118.0 \mathrm{mM}$ $\mathrm{NaCl}, 4.7 \mathrm{mM} \mathrm{KCl}, 2.5 \mathrm{mM} \mathrm{CaCl}_{2}, 1.2 \mathrm{mM} \mathrm{MgSO}_{4}, 25.0$ $\mathrm{mM} \mathrm{NaHCO}_{3}, 1.2 \mathrm{mM} \mathrm{KH}_{2} \mathrm{PO}_{4}$, and $10.0 \mathrm{mM}$ glucose in distilled water. Changes in isometric tension were measured by attaching the upper end of the ring to an isometric tension transducer (MLT0201/RAD, ADInstruments, Australia). Changes in tension were recorded on a PowerLab 8/30 device (ML870B60/C-V, ADInstruments). Intrinsic tone was induced by allowing the rings to equilibrate under an applied tension of $1 \mathrm{~g}$ for $60 \mathrm{~min}$.

Concentration-response curves were generated for sildenafil $(0.1 \mu \mathrm{M}$ to $0.6 \mathrm{mM}, 5 \mathrm{~min}$ for each concentration) in intact epithelial tracheal rings precontracted with carbachol (CCh) in the absence and presence of $5 \mathrm{mM}$ tetraethylammonium chloride (TEA, a nonspecific blocker of $\mathrm{K}^{+}$channels), $3 \mathrm{mM}$ 4-aminopyridine (4-AP, a selective blocker of voltage-sensitive $\mathrm{K}^{+}$channels), $1 \mu \mathrm{M}$ glybenclamide (a selective blocker of ATP-sensitive $\mathrm{K}^{+}$channels), $1 \mu \mathrm{M}$ tetrodotoxin (TTX, a blocker of fast $\mathrm{Na}^{+}$channels), or $50 \mu \mathrm{M}$ L-nitro-arginine methyl ester (L-NAME, a nitric oxide [NO] synthase inhibitor), which were added $10 \mathrm{~min}$ (TEA, 4-AP, TTX) or 20 min (glybenclamide, L-NAME) before the addition of the first $\mathrm{CCh}$ concentration. The relaxant effect of sildenafil was also evaluated in epithelium-denuded tracheal rings with epithelium removal confirmed by microscopy. Concentration-effect curves were also generated for NO donor agents (3 min for each concentration), including sodium nitroprusside (SNP) and (S)-nitroso- $N$ acetylpenicillamine (SNAP) in the absence and presence of a single concentration of sildenafil $(10 \mu \mathrm{M})$, which was 
added 5 min before the first concentration of a given NO donor. The tracheal rings of control and OVA-challenged rats were used separately to evaluate the effects of sildenafil on the concentration-effect curve induced by $\mathrm{CCh}$, as well as on the contractile responses induced by capacitative $\mathrm{Ca}^{2+}$ entry or gene expression.

\section{Total RNA isolation}

Tracheal rings were obtained, and tissues were isolated from the edges attached to the cartilage. Total RNA was isolated from different animals of a given group. The animals' tissues were pooled to obtain samples of tracheal tissues, which were obtained from the dorsal paries membranaceus. Excess liquid was removed with absorbent paper, and the tissues were then weighed and stored at $-80^{\circ} \mathrm{C}$ until used for the analysis. The average quantity of tissue isolated from a single trachea was $\sim 8 \mathrm{mg}$. The average amount of tissue per sample from each group was $\sim 30 \mathrm{mg}$ (4 rats). Total RNA was isolated from each sample using the RNeasy Mini kit (Qiagen, USA) and a QIAcube automation device (Qiagen).

Briefly, the samples were incubated with $\beta$-mercaptoethanol-containing lysis buffer in a volume of $600 \mu \mathrm{L}$. Sample grinding was performed using a cell disruptor composed of a dremel tool (Polytron PT 10-35 GT, Switzerland) with autoclavable steel rotating blades. After membrane disruption and acid nucleic release into the medium, the solution was centrifuged at $14,000 \mathrm{~g}$ for $3 \mathrm{~min}$, and the supernatant was transferred to a 2-mL plastic tube (Eppendorf, Germany). Next, the tube was placed in a QIAcube (Qiagen) device, which enables the automatic purification of highly pure nucleic acids following predetermined protocols according to manufacturer instructions.

\section{Reverse transcriptase reaction}

To evaluate the gene expression of TRPCs, the isolated RNA was transformed to cDNA by a reverse transcriptase reaction using a SuperScript ${ }^{\mathrm{TM}}$ III Reverse Transcriptase System (Invitrogen, USA). Briefly, RNA samples $(1 \mu \mathrm{g})$ were incubated with $1 \mu \mathrm{L}$ oligo(dT) 20 primer $(50 \mu \mathrm{M})$ and $1 \mu \mathrm{L}$ of a mixture of nucleotides (dNTP mix, $10 \mathrm{mM}$ ) in Milli-Q water to a final volume of $10 \mu \mathrm{L}$, which was named reaction $A$. This reaction was warmed to $65^{\circ} \mathrm{C}$ for $5 \mathrm{~min}$ to denature the RNA and to anneal the oligo(dT) 20 primer at the end of the poly $(A) m R N A$ tail. The reaction was then cooled on ice for at least $1 \mathrm{~min}$. This solution was supplemented (reaction B) with $2 \mu \mathrm{L}$ cDNA synthesis buffer (10X), $4 \mu \mathrm{L} \mathrm{MgCl} 2$ (25 $\mathrm{mM}), 2 \mu \mathrm{L} 0.1 \mathrm{M}$ dithiothreitol, $1 \mu \mathrm{L}$ RNAseOUT ${ }^{\mathrm{TM}}$ solution (40 U/ $/ \mathrm{L}$, Invitrogen), and $1 \mu \mathrm{L}$ SuperScript ${ }^{\mathrm{TM}}$ III RT (200 $\mathrm{U} / \mathrm{mL})$. The tube containing the two reactions $(20 \mu \mathrm{L})$ was transferred to a thermal cycler initially for $50 \mathrm{~min}$ at a temperature of $50^{\circ} \mathrm{C}$. After this period, the reaction mixture was heated to $85^{\circ} \mathrm{C}$ for $5 \mathrm{~min}$ and then immediately cooled to $4^{\circ} \mathrm{C}$. To end the process, $1 \mu \mathrm{L}$ RNase $\mathrm{H}$ was added to the synthesized cDNAand the preparation was incubated for 20 min at $37^{\circ} \mathrm{C}$. The synthesized cDNA was kept in a freezer at $-20^{\circ} \mathrm{C}$ until its amplification by real-time polymerase chain reaction $(\mathrm{PCR})$.

\section{Real-time PCR (qPCR)}

The gene expression of TRPC1, TRPC4, TRPC5, and TRPC6 was assayed using an iQ5 Real-Time PCR Detection System (Bio-Rad, USA). Phospholipase $A_{2}$ (tyrosine 3-monooxygenase/tryptophan 5-monooxygenase activation protein zeta polypeptide) was used as the reference gene (YHWAZ). DNA primers for all genes (Table 1) were designed on the basis of mRNA sequences obtained from the National Center for Biotechnology Information (http:// www.ncbi.nlm.nih.gov; accessed February 4, 2011).

Real-time PCR assays were performed in a final volume of $25 \mu \mathrm{L}$ of a medium containing $12.5 \mu \mathrm{L}$ iQ Supermix (standard buffer for amplification with reagents such as DNA polymerase, dNTPs, and saline buffer at optimal concentrations for real-time PCR assays), $200 \mathrm{nM}$ primers, and $2 \mu \mathrm{L}$ CDNA of the samples. Negative samples were also tested, with the cDNA being replaced with autoclaved Milli-Q water. The PCR conditions were as follows: an initial denaturation period of $3 \mathrm{~min}$ at $95^{\circ} \mathrm{C}$, followed by 40 cycles for gene amplification. Each cycle consisted of an initial denaturation phase of $30 \mathrm{~s}$ at $95^{\circ} \mathrm{C}$, followed by an annealing phase of $30 \mathrm{~s}$ at $60^{\circ} \mathrm{C}$ and an extension phase of $45 \mathrm{~s}$ at $72^{\circ} \mathrm{C}$. The samples were then subjected to an extension step of $3 \mathrm{~min}$ at $72^{\circ} \mathrm{C}$.

To ensure the specificity of the amplifications applied (i.e., to determine whether the formed products were specific for the tested genes), we constructed a fusion curve (i.e., a melting curve) after each reaction, in which the reaction temperature was subsequently increased by $1^{\circ} \mathrm{C}$ every $20 \mathrm{~s}$, beginning at the annealing temperature of a given primer and ending at $95^{\circ} \mathrm{C}$. Throughout the curve construction process, the changes in fluorescence were measured, and the data obtained with the iQ5 Optical System software (version 2.0; Bio-Rad) were based on the values of the threshold cycle, in which the observed

Table 1. Oligonucleotide sequence of primers used in the qPCR assays.

\begin{tabular}{ll}
\hline Gene & Primer sequences [5'-3'; sense (S) and antisense (AS)] \\
\hline TRPC1 & S - CTTGGCAACTTTTGCCCTCA \\
& AS - AAAGGCGAAAAGCCCTTCTG \\
TRPC4 & S - CCAATGTCAAAGCCCAGCAT \\
& AS - CTGCGTGGTCGGCAATTAGT \\
TRPC5 & S - CAACAATTGCTGGCCACCTT \\
& AS - GGATGCTGTGTGGCAGATGA \\
TRPC6 & S - TCTGAAGTGAAGTCGGTGGTCA \\
& AS - CCGCATCATCCTCAATTTCC \\
YHWAZ & S - GCTACTTGGCTGAGGTTGCT \\
& AS - TGCTGTGACTGGTCCACAAT \\
\hline
\end{tabular}



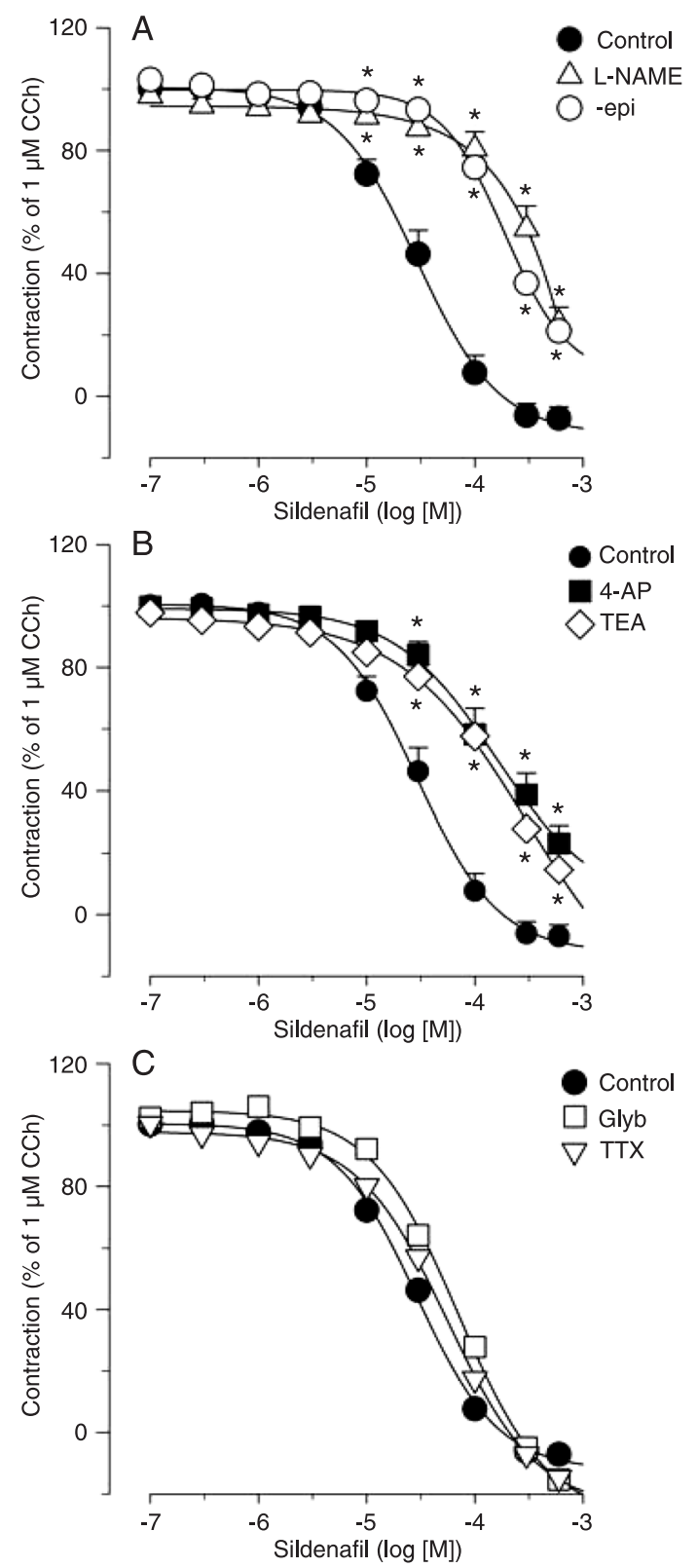

Figure 1. Relaxant effect of sildenafil on sustained contraction induced by $\mathrm{CCh}$ in rat tracheal rings. The addition of $1 \mu \mathrm{M} \mathrm{CCh}$ to tracheal rings from control rats produced sustained contraction. After a steady-state CCh-induced contraction was reached, cumulative concentrations of sildenafil were added, and the relaxant effect was evaluated in the absence (filled circles) or presence of L-NAME (50 $\mu \mathrm{M}$; triangles up), 4-AP (1 mM; filled squares), TEA (5 mM; diamonds), glybenclamide (Glyb; $10 \mu \mathrm{M}$; open squares), or TTX $(1 \mu \mathrm{M}$; triangles down). The relaxant effects of sildenafil were also evaluated in epithelium-denuded tracheal rings (-epi; open circles). Data are reported as means \pm SEM of 6-12 experiments. $\mathrm{CCh}=$ carbachol; L-NAME $=\mathrm{L}$-nitro-arginine methyl ester; 4-AP = 4-aminopyridine; TEA = tetraethylammonium chloride; $\mathrm{TTX}=$ tetrodotoxin. ${ }^{*} \mathrm{P}<0.05$ compared to the same concentration in the control curve (two-way ANOVA followed by the Holm-Sidak test) fluorescence is 10 -fold higher than the basal fluorescence for each PCR assay. Gene expression was obtained by applying the mathematical method of Pfaffl (17).

\section{Solutions and drugs}

The physiological salt solution was a modified KrebsHenseleit solution of the following composition: $118.0 \mathrm{mM}$ $\mathrm{NaCl}, 4.7 \mathrm{mM} \mathrm{KCl}, 2.5 \mathrm{mM} \mathrm{CaCl}_{2}, 1.2 \mathrm{mM} \mathrm{MgSO}_{4}, 25.0$ $\mathrm{mM} \mathrm{NaHCO}_{3}, 1.2 \mathrm{mM} \mathrm{KH}_{2} \mathrm{PO}_{4}$, and $10.0 \mathrm{mM}$ glucose. Solutions with a high $\mathrm{KCl}$ content were prepared by adding $\mathrm{KCl}$ to the bath from a 3-M KCl solution in distilled water. CCh, TTX, TEA, thapsigargin, and L-NAME were purchased from Sigma, and sildenafil citrate was kindly provided by Pfizer (UK). Salts and reagents (all of analytical grade) were purchased from Sigma or Merck (Germany).

\section{Statistical analysis}

Data are reported as means \pm SEM and $N$ indicates the number of experiments. The $\mathrm{EC}_{50}$ (i.e., the concentration of agonist at which $50 \%$ of the maximal response was observed) or $\mathrm{IC}_{50}$ values (i.e., the concentration of sildenafil or of an NO donor at which $50 \%$ of a CCh-induced response was inhibited) were calculated by interpolation from semilogarithmic plots and are reported as geometric means (95\% confidence interval). One-way or two-way analysis of variance (ANOVA) followed by the Holm-Sidak post hoc test were employed to compare differences between treatments. $\mathrm{IC}_{50}$ values were compared using the Mann-Whitney or Wilcoxon test as appropriate. $E_{\max }$ values were compared using the unpaired Student $t$-test. Statistical significance was accepted when $\mathrm{P}<0.05$.

\section{Results}

\section{Effects of sildenafil on the sustained contractions induced by carbachol in rat tracheal rings}

In a group of tracheal rings obtained from rats not subjected to antigen challenge, sildenafil $(0.1 \mu \mathrm{M}$ to 0.6 $\mathrm{mM}$ ) fully relaxed the sustained contractions induced by a submaximal concentration of carbachol $(1 \mu \mathrm{M})$ in a concentration-dependent manner $(P<0.001$, ANOVA; Figure 1), with an $\mathrm{IC}_{50}$ of $27.2(17.5-42.1) \mu \mathrm{M}(\mathrm{N}=12)$. The concentration-effect curve for the relaxant effect induced by sildenafil was shifted to the right by pretreatment of the tracheal rings with L-NAME, TEA, and 4-AP, which significantly increased $\left(P<0.05\right.$, Mann-Whitney test) the $\mathrm{IC}_{50}$ values of sildenafil-induced relaxation. The $\mathrm{IC}_{50}$ values are shown in Table 2, which shows that epithelium removal also decreased the relaxant effect of sildenafil, whereas neither TTX nor glybenclamide changed the inhibitory potency of sildenafil to relax carbachol-elicited contractions.

\section{Effects of sildenafil on the relaxing effects induced by NO donors}

The cumulative addition of substances with NO- 
Table 2. $\mathrm{IC}_{50}$ values for the myorelaxant effects induced by sildenafil on sustained contraction induced by carbachol in tracheal rings of naive rats.

\begin{tabular}{lc}
\hline Treatment & $\mathrm{IC}_{50}(\mu \mathrm{M})$ \\
\hline Control $(\mathrm{N}=12)$ & $27.2(17.5-42.1)$ \\
L-NAME $(50 \mu \mathrm{M})(\mathrm{N}=7)$ & $348.1(248.0-488.5)^{*}$ \\
TEA $(5 \mathrm{mM})(\mathrm{N}=10)$ & $119.5(57.4-248.9)^{*}$ \\
4-AP $(1 \mathrm{mM})(\mathrm{N}=6)$ & $174.9(70.9-431.4)^{*}$ \\
Epithelium-denuded $(\mathrm{N}=7)$ & $232.2(129.6-416.3)^{*}$ \\
TTX $(1 \mu \mathrm{M})(\mathrm{N}=11)$ & $43.9(23.5-82.0)$ \\
Glybenclamide $(10 \mu \mathrm{M})(\mathrm{N}=7)$ & $48.3(21.3-109.5)$ \\
\hline
\end{tabular}

Tracheal rings from naive rats were treated in vitro with sildenafil $(0.1 \mu \mathrm{M}$ to $0.6 \mathrm{mM})$ during the steady state of a sustained contraction induced by a submaximal concentration of carbachol (1 $\mu \mathrm{M}$ ) in the absence (control) or presence of L-NAME, TEA, 4-AP, TTX, or glybenclamide. In a separate group, experiments with sildenafil $(0.1 \mu \mathrm{M}$ to $0.6 \mathrm{mM})$ alone were performed in epitheliumdenuded tracheal rings. $I_{50}$ is reported as the geometric mean ( $95 \%$ confidence interval). $\mathrm{N}$ indicates the number of experiments. L-NAME = L-nitro-arginine methyl ester; TEA = tetraethylammonium chloride; 4-AP = 4-aminopyridine; $\mathrm{TTX}=$ tetrodotoxin. ${ }^{*} \mathrm{P}<$ 0.05 compared to control (Mann-Whitney test).

Table 3. $I C_{50}$ values for the myorelaxant effects induced by the nitric oxide donors SNP and SNAP on the sustained contraction induced by carbachol in tracheal rings of naive rats.

\begin{tabular}{|c|c|c|}
\hline \multirow[t]{2}{*}{ Treatment } & \multicolumn{2}{|c|}{$\mathrm{IC}_{50}(\mu \mathrm{M})$} \\
\hline & Control & Sildenafil $(10 \mu \mathrm{M})$ \\
\hline SNP (N = 6) & $0.30(0.12-0.72)$ & $0.04(0.01-0.19)^{\star}$ \\
\hline SNAP $(N=5)$ & $59.99(24.32-143.12)$ & $4.78(1.89-12.06)^{*}$ \\
\hline
\end{tabular}

Tracheal rings from rats not subjected to antigen challenge received cumulative concentrations of SNP or SNAP during the steady state of a sustained contraction induced by a submaximal concentration of carbachol $(1 \mu \mathrm{M})$ in the absence (control) or presence of sildenafil $(10 \mu \mathrm{M})$. $I C_{50}$ is reported as the geometric mean (95\% confidence interval). $\mathrm{N}$ indicates the number of experiments. SNP = sodium nitroprusside; SNAP $=(S)$-nitroso- $N$ acetylpenicillamine. ${ }^{*} \mathrm{P}<0.05$ compared with control of the same treatment (Wilcoxon test).

releasing properties, such as SNP ( $1.0 \mathrm{nM}$ to $0.1 \mathrm{mM})$ and SNAP ( $1.0 \mathrm{nM}$ to $1.0 \mathrm{mM})$, on the plateau of a sustained contraction induced by carbachol $(1 \mu \mathrm{M})$ induced a relaxant response (Figure 2) in a concentration-dependent manner $(\mathrm{P}<0.001, \mathrm{ANOVA})$, with $\mathrm{IC}_{50}$ values of 0.30 $(0.09-0.87) \mu \mathrm{M}(\mathrm{N}=5)$ and $58.99(24.32-143.12) \mu \mathrm{M}$ $(N=5)$, respectively. As shown in Table 3, in the presence of a single concentration of sildenafil $(10 \mu \mathrm{M})$, the concentration-effect curves for SNP and SNAP were significantly shifted to the left because their $\mathrm{IC}_{50}$ values were
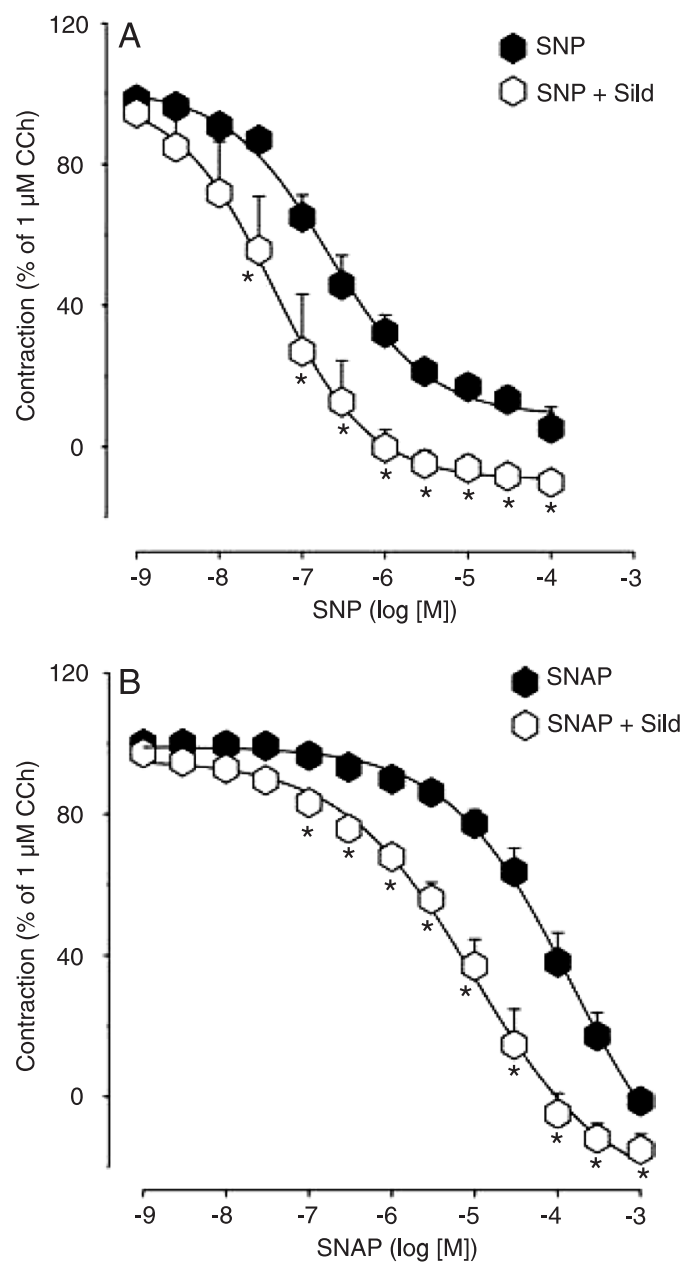

Figure 2. Effect of sildenafil on the concentration-effect curve of the nitric oxide donors SNP and SNAP on the sustained contraction induced by $\mathrm{CCh}$ in rat tracheal rings. In tracheal rings contracted with $1 \mu \mathrm{M} \mathrm{CCh}$, the concentration-dependent relaxant effects of (A) SNP (1.0 nM to $0.1 \mathrm{mM}$ ) and (B) SNAP (1.0 nM to $1.0 \mathrm{mM}$ ) were evaluated in the absence (filled hexagons) or presence (open hexagons) of $10 \mu \mathrm{M}$ sildenafil (Sild). Data are reported as means \pm SEM of 5-6 experiments in each group. CCh $=$ carbachol; SNP = sodium nitroprusside; SNAP = (S)-nitroso- $N$ acetylpenicillamine. ${ }^{*} P<0.05$ compared to the same concentration in the control curve (two-way ANOVA followed by the HolmSidak test).

significantly decreased $(P<0.05$, Wilcoxon test).

Effects of sildenafil on the concentration-effect curves for carbachol in isolated tracheal rings from rats subjected to antigen challenge

Tracheal contractile responses were determined in vitro $24 \mathrm{~h}$ after the animals were challenged with saline (control) or OVA in another group of animals. Full concentrationresponse curves for CCh $(1.0 \mathrm{nM}$ to $0.3 \mathrm{mM})$ showed concentration-dependent tracheal contractions $(P<0.001$, 
ANOVA) both in control ( $N=7)$ and OVA-challenged tracheal rings (challenged; $N=5$ ). In sildenafil-untreated tracheal rings (Figure $3 \mathrm{~A}$ ), OVA-challenged tissues displayed con-

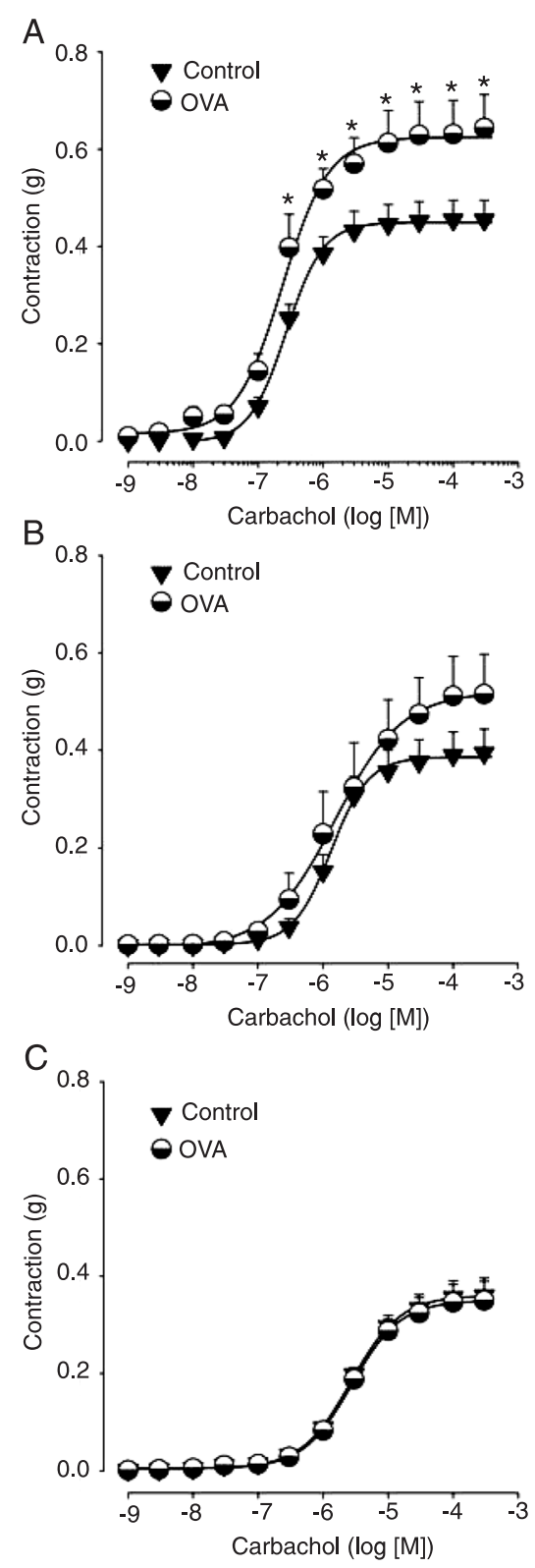

Figure 3. Effects of sildenafil on the concentration-effect curve of $\mathrm{CCh}$ in tracheal rings from control or OVA-challenged rats. Contractile responsiveness to cumulative additions of CCh $(1.0 \mathrm{nM}$ to $0.3 \mathrm{mM}$ ) was determined in tissues from control $(\mathrm{N}=7)$ or ovalbumin-sensitized $(\mathrm{N}=5)$ animals aerosolized $24 \mathrm{~h}$ earlier with either saline (filled triangles down) or ovalbumin (half-filled circles). The concentration-effect curves were generated in the absence $(A)$ or presence of $10 \mu \mathrm{M}$ sildenafil (B) or $30 \mu \mathrm{M}$ sildenafil (C). Data are reported as means $\pm \mathrm{SEM}$. $\mathrm{CCh}=$ carbachol; OVA = ovalbumin. ${ }^{*} P<0.05$ compared to the same concentration in the control curve (two-way ANOVA followed by the Holm-Sidak test). tractile responses to $\mathrm{CCh}$, with $\mathrm{E}_{\max }$ values of $0.644 \pm 0.068$ $\mathrm{g}$ at $0.3 \mathrm{mM}$ (Table 4), which were significantly higher than those observed in control tissues challenged with saline $(0.455 \pm 0.040 \mathrm{~g} ; \mathrm{P}<0.05$, unpaired Student $t$-test $)$. The $\mathrm{EC}_{50}$ for CCh was $0.26(0.21-0.33) \mu \mathrm{M}$ in control tissues and $0.23(0.15-0.35) \mu \mathrm{M}$ in challenged tissues, with no significant difference between values ( $P>0.05$, Mann-Whitney test). Tissues pretreated with $10 \mu \mathrm{M}$ sildenafil (Figure 3B) had $E_{\text {max }}$ values of $0.515 \pm 0.082 \mathrm{~g}$ for contractile responses to CCh after OVA challenge, but these values were not significantly different from control $(P>0.05$, unpaired Student $t$-test). When treated with $30 \mu \mathrm{M}$ sildenafil (Figure $3 \mathrm{C}$ ), control and OVA-challenged tracheal rings had similar CCh-induced concentration-effect curve profiles, with no differences in their $E_{\max }$ values, but the values were significantly lower than those obtained in sildenafil-untreated tissues $(P<0.05$, unpaired Student $t$-test). Conversely, the $\mathrm{EC}_{50}$ values were significantly higher in tissues treated with $30 \mu \mathrm{M}$ sildenafil than in sildenafil-untreated tracheal rings, but these values were not significantly different between control and OVA-challenged tissues $(P>0.05)$.

\section{Effects of sildenafil on the contractions induced by capacitative $\mathrm{Ca}^{2+}$ entry}

In tissues obtained from control animals not subjected to antigen challenge, sildenafil concentration-dependently reversed $(P<0.05, A N O V A)$ the contractions induced by the addition of $\mathrm{Ca}^{2+}$ to the extracellular medium after treat-

Table 4. $E C_{50}$ and $E_{\max }$ values of the concentration-effect curves generated with carbachol in isolated tracheal rings obtained from control or OVA-challenged rats.

\begin{tabular}{lcc}
\hline & $\mathrm{EC}_{50}(\mu \mathrm{M})$ & $\mathrm{E}_{\max }(\mathrm{g})$ \\
\hline $\begin{array}{l}\text { Sildenafil-untreated } \\
\quad \text { Control }\end{array}$ & $0.26(0.21-0.33)$ & $0.455 \pm 0.040$ \\
$\quad$ Challenged & $0.23(0.15-0.35)$ & $0.644 \pm 0.068^{\mathrm{a}}$ \\
Sildenafil $(10 \mu \mathrm{M})$ & & \\
$\quad$ Control & $1.25(0.85-1.84)^{\mathrm{a}}$ & $0.394 \pm 0.049$ \\
$\quad$ Challenged & $1.63(0.37-7.11)^{\mathrm{b}}$ & $0.515 \pm 0.082$ \\
Sildenafil $(30 \mu \mathrm{M})$ & & \\
$\quad$ Control & $2.35(1.69-3.27)^{\mathrm{a}}$ & $0.360 \pm 0.036^{\mathrm{c}}$ \\
$\quad$ Challenged & $3.66(1.59-8.44)^{\mathrm{b}}$ & $0.350 \pm 0.039^{\mathrm{d}}$ \\
\hline
\end{tabular}

Tracheal rings from ovalbumin (OVA)-sensitized rats received cumulative concentrations of carbachol to generate a concentrationeffect curve in the absence (sildenafil-untreated) or presence of sildenafil $(10$ or $30 \mu \mathrm{M})$. $E_{50}$ is reported as the geometric mean (95\% confidence interval). Data are reported for 5-7 experiments. ap $<0.05$ compared to sildenafil-untreated control tissues (Mann-Whitney test); ${ }^{b} \mathrm{P}<0.05$ compared to sildenafil-untreated challenged tissues (Mann-Whitney test); ${ }^{\mathrm{C} P}<0.05$ compared to sildenafil-untreated control tissues (unpaired Student $t$-test); dP $<0.05$ compared to sildenafil-untreated challenged tissues (unpaired Student $t$-test). 
ment of the tracheal rings with $1 \mu \mathrm{M}$ thapsigargin and $10 \mu \mathrm{M}$ carbachol under $\mathrm{Ca}^{2+}$-free conditions to deplete intracellular $\mathrm{Ca}^{2+}$ stores. Full relaxation was observed at a sildenafil concentration of $100 \mu \mathrm{M}(\mathrm{N}=4$; Figure 4A).

The contractions induced by $\mathrm{Ca}^{2+}$ restoration in the extracellular medium were $42.9 \pm 7.3 \%$ of the reference contraction obtained with $60 \mathrm{mM} \mathrm{K}^{+}$under normal $\mathrm{Ca}^{2+}$ containing conditions (Figure 4B). When $30 \mu \mathrm{M}$ sildenafil was added before $\mathrm{Ca}^{2+}$, it decreased $\mathrm{Ca}^{2+}$-induced contractions to $10.8 \pm 3.7 \%(N=10)$, a value significantly lower than control $(P<0.05$, unpaired Student $t$-test). Tracheal rings obtained from OVA-challenged rats contracted with increased amplitude in response to the addition of $\mathrm{Ca}^{2+}$ $(98.0 \pm 11.8 \% ; N=6)$, with the amplitude being significantly increased compared to control tissues. Sildenafil also significantly decreased $\mathrm{Ca}^{2+}$-induced contractions to $22.7 \pm 5.4 \%$ in tracheal rings of OVA-challenged animals ( $P<0.05$, unpaired Student $t$-test).

\section{TRPC gene expression by RT-PCR analysis of rat tracheal tissue}

The expression of four genes belonging to the TRPC subfamily was investigated in tissue samples obtained from rat tracheas. TRPC1, TRPC4, TRPC5, and TRPC6 were all expressed (Figure 5), and their expression profiles changed according to exposure to antigenic challenge with or without previous sildenafil (20 or $50 \mathrm{mg} / \mathrm{kg}$, ip) treatment. In fact, TRPC1 and TRPC4 expression increased after OVA challenge (Figure $6 \mathrm{~A}$ and $\mathrm{B}$ ), whereas the expression of TRPC5 (Figure 6C) and TRPC6 (Figure 6D) did not change after OVA inhalation. In OVA-challenged rats, sildenafil also significantly altered the expression of TRPC genes. For ex- ample, TRPC1 expression was further increased in tissues of OVA-challenged animals after treatment with $50 \mathrm{mg} / \mathrm{kg}$ sildenafil $(P<0.05$, Holm-Sidak test; Figure $6 \mathrm{~A})$. In contrast, the relative expression of TRPC5, which did not exhibit changes after OVA challenge, was significantly decreased after treatment with $50 \mathrm{mg} / \mathrm{kg}$ sildenafil $(P<0.05$; Figure 6C). Interestingly, TRPC6 expression increased despite the ineffectiveness of OVA in inducing a change in its expression ( $P<0.05$; Figure 6D), whereas TRPC4 expression, which was increased by the antigen challenge, did not change even after treatment with $50 \mathrm{mg} / \mathrm{kg}$ sildenafil.

\section{Discussion}

The present in vitro study showed that sildenafil decreased the tracheal hyperresponsiveness to CCh that occurred after exposure of sensitized animals to antigen challenge by OVA inhalation. In addition to the more evident effects of sildenafil against hyperresponsive CCh-induced contractions, it also more efficiently inhibited OVA-enhanced contractions induced by activation of capacitative $\mathrm{Ca}^{2+}$ entry, which is triggered by depletion of internal $\mathrm{Ca}^{2+}$ stores. Our data also showed that antigen challenge modified the gene expression of several members of the TRPC subfamily in the rat trachea, a phenomenon modifiable by PDE5 inhibition caused by sildenafil pretreatment.

The beneficial effects of sildenafil in the treatment of male erectile dysfunction and pulmonary hypertension are attributable to its ability to potentiate the vasorelaxant effect of $\mathrm{NO}$ on vascular smooth muscle cells, which are relaxed by sildenafil-induced cGMP accumulation in response to generated NO $(1,2)$. The present study first determined the
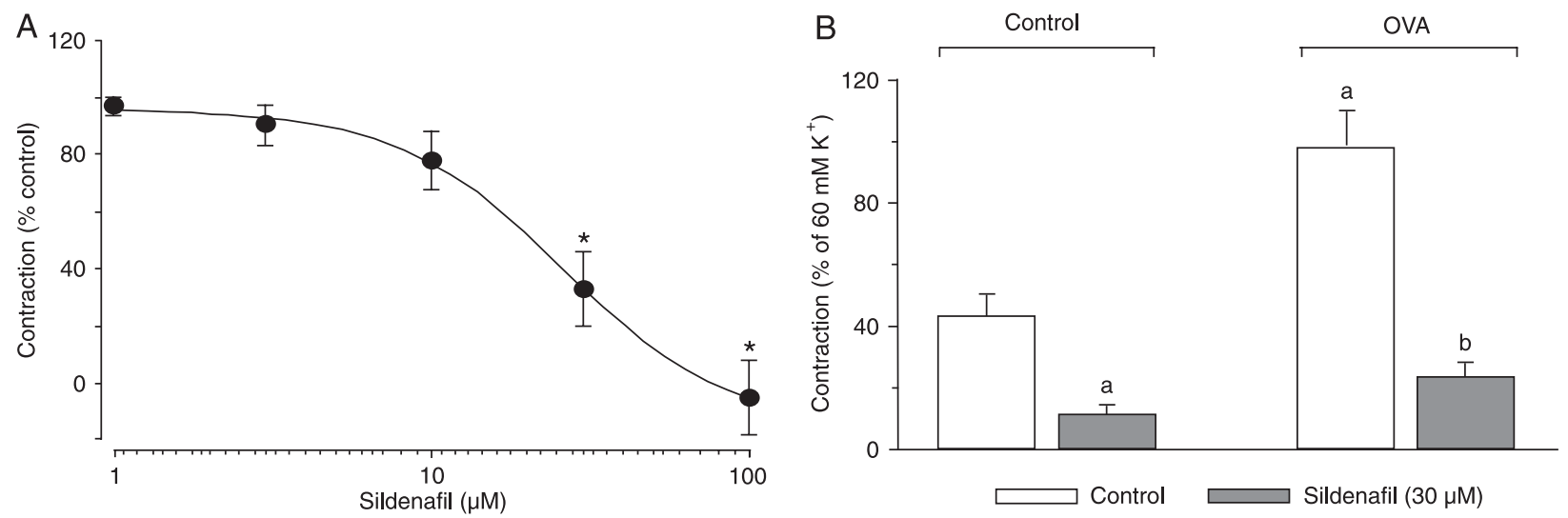

Figure 4. Effects of sildenafil on tracheal contractions induced by capacitative $\mathrm{Ca}^{2+}$ entry. $A$, Inhibitory effects of the addition of cumulative concentrations of sildenafil $(1-100 \mu \mathrm{M} ; \mathrm{N}=4)$ on the steady state of a sustained contraction induced by extracellular $\mathrm{Ca}^{2+}$ restoration (i.e., the addition of $2.5 \mathrm{mM} \mathrm{Ca}^{2+}$ to the bath chamber) after the treatment of tissue with $1 \mu \mathrm{M}$ thapsigargin and $10 \mu \mathrm{M}$ CCh under $\mathrm{Ca}^{2+}$-free conditions. $B$, Contractions induced by $\mathrm{Ca}^{2+}$ restoration were performed in the absence or presence of $30 \mu \mathrm{M}$ sildenafil in tissues from control $(N=10)$ animals or from OVA-challenged rats $(N=6)$. Data are reported as means $\pm S E M$. CCh $=$ carbachol; OVA $=$ ovalbumin. ${ }^{*} \mathrm{P}<0.05$ compared to control values (Holm-Sidak test); ${ }^{a} \mathrm{P}<0.05$ compared to control values in the absence of sildenafil (unpaired Student $t$-test); ${ }^{\mathrm{b} P}<0.05$ compared to OVA-challenged values in the absence of sildenafil (unpaired Student $t$-test). 
mechanism of relaxation caused by sildenafil in tracheal smooth muscles, mainly by assessing whether its relaxant effects depended on the NO-cGMP-K ${ }^{+}$channel pathway. Sildenafil shifted the concentration-effect curve to the left in response to NO donors, such as SNP and SNAP, whereas its inhibitory action was decreased by the treatment of tracheal rings with L-NAME and by epithelium removal, indicating that the action depended upon the inhibitory drive offered by $\mathrm{NO}$ production and the release of epithelium-derived relaxing factors (18-20). Because the relaxant effects were also decreased by pretreatment of the tracheal rings with TEA and 4-AP, we concluded that the increased intracellular cGMP levels induced by sildenafil may elicit $\mathrm{K}^{+}$channel
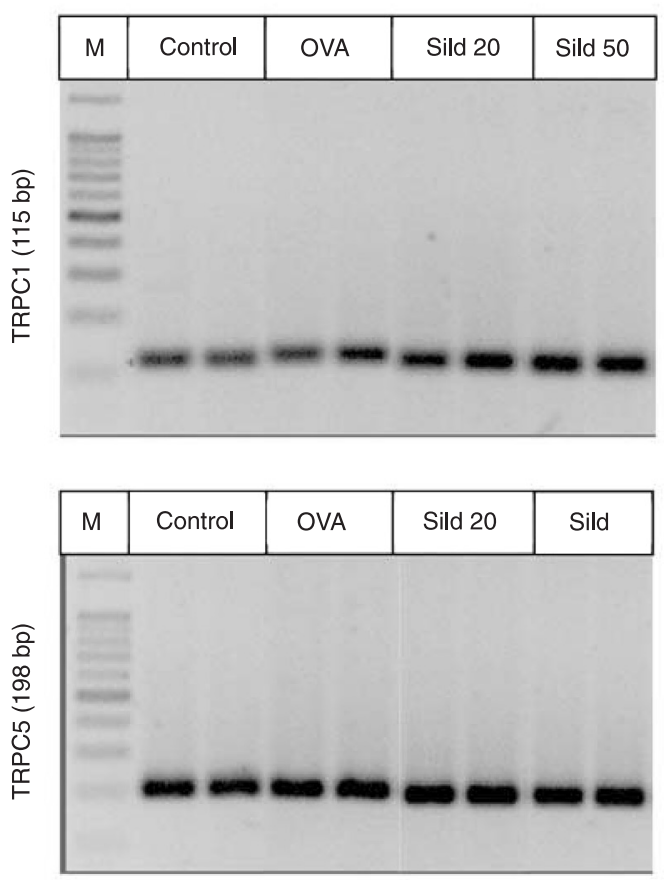

opening (more specifically, voltage-gated $\mathrm{K}^{+}$channels), which in turn hyperpolarizes the transmembrane resting potential and relaxes smooth muscles by governing $\mathrm{Ca}^{2+}$ influx via voltage-dependent $\mathrm{Ca}^{2+}$ channels (21). Glybenclamide and TTX did not alter the ability of sildenafil to inhibit tracheal contractions, and its relaxant effects are unlikely to be mediated by the participation of $\mathrm{K}_{\mathrm{ATP}}$ or neuronal discharges onto tracheal smooth muscle cells.

An interesting action was the ability of sildenafil to reduce the development of tracheal hyperresponsiveness to CCh in vitro. In the presence of sildenafil, the tracheal rings of OVA-challenged animals responded to $\mathrm{CCh}$ with a profile similar to tissues obtained from animals not subjected
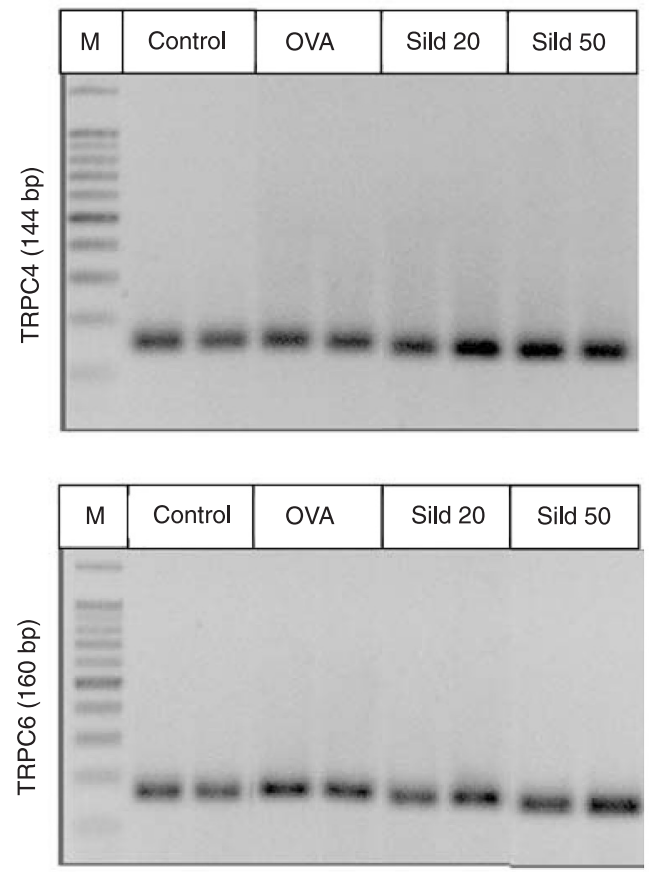

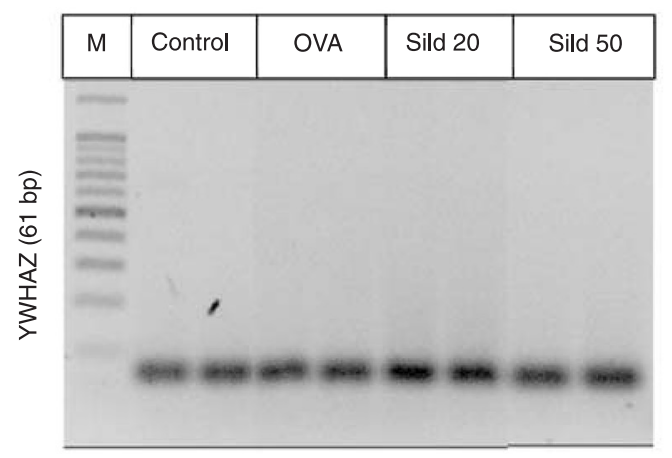

Figure 5. Agarose gel (2\%) stained with ethidium bromide, showing the gene expression of TRPC1 (115 bp), TRPC4 (144 bp), TRPC5 (198 bp), TRPC6 (160 bp), and YWHAZ (61 bp) in the rat trachea. Lane M, 100-bp molecular marker; lane Control, samples from control rats; lane OVA, samples from rats challenged with ovalbumin (OVA); lane Sild 20, samples obtained from rats treated with $20 \mathrm{mg} / \mathrm{kg}$ sildenafil and challenged with OVA; lane Sild 50 , samples obtained from rats treated with $50 \mathrm{mg} / \mathrm{kg}$ sildenafil and challenged with OVA. The expression of YWHAZ was used as a reference. 
to antigen challenge. These results indicate that tissues exposed to an antigen-induced inflammatory process may be more responsive to the relaxing effects of sildenafil. Our data are consistent with those of Toward et al. (22), who reported that sildenafil decreased the hyperresponsiveness to inhaled histamine in guinea pigs exposed to OVA or lipopolysaccharides. In contrast, Al Qadi-Nassar et al. (23) reported that sildenafil did not affect the airway responsiveness to methacholine in sensitized BP2 mice, but when combined with L-arginine, it dramatically enhanced the airway responsiveness to inhaled methacholine. As the inflammatory process elicited by antigen challenge often involves epithelial damage, we conclude that smooth muscle cells of the rat trachea are more susceptible to the relaxant influences of PDE5 inhibition after antigen challenge. This conclusion is supported by the fact that in epithelium-denuded preparations, the inhibitory effects of sildenafil were clearly blunted. However, in view of the differences between these experimental animal models, this observation deserves further study.

We also evaluated whether the enhanced contractile responses of tracheal rings after antigen challenge involved a greater recruitment of store-operated channels, which may trigger capacitative $\mathrm{Ca}^{2+}$ entry, a mechanism physiologically involved in maintaining sustained $\mathrm{Ca}^{2+}$ influx to
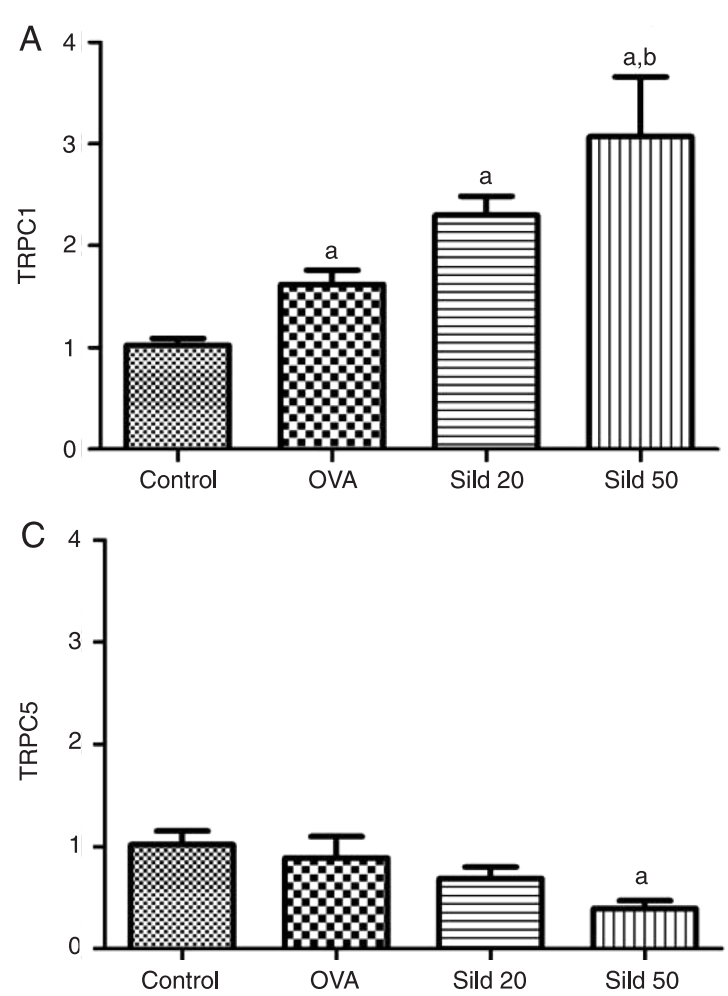

refill $\mathrm{Ca}^{2+}$ stores in the sarcoplasmic reticulum (24). Under $\mathrm{Ca}^{2+}$-free conditions, the addition of $\mathrm{Ca}^{2+}$ to the extracellular medium after treatment with thapsigargin promoted a contractile response consistent with the well-known increase in cytosolic $\mathrm{Ca}^{2+}$ induced by store-regulated mechanisms (25). Interestingly, contractions induced by $\mathrm{Ca}^{2+}$ were higher in tissues obtained from OVA-challenged rats than from control animals, indicating that antigen challenge activated this phenomenon with a more pronounced participation of capacitative $\mathrm{Ca}^{2+}$ entry into antigen-challenged tissues. Although a direct influence of antigen challenge on capacitative $\mathrm{Ca}^{2+}$ entry has not been completely demonstrated hitherto, previous reports demonstrated the involvement of protein expression of store-operated $\mathrm{Ca}^{2+}$ channels in allergic states (26-28). Sildenafil more evidently reduced the contractions induced by capacitative $\mathrm{Ca}^{2+}$ entry in OVA-challenged tissues, and we suspect that it may alter the expression of genes related to the proteins of the TRPC subfamily, the so-called store-operated $\mathrm{Ca}^{2+}$ channels (29).

The expression of TRPC genes in airways has already been described. It is not restricted to smooth muscle cells and is also found in epithelia, neutrophils, eosinophils, and T-lymphocytes, all of which are involved in airway inflammation (30-32). For example, TRPC1 was detected in smooth
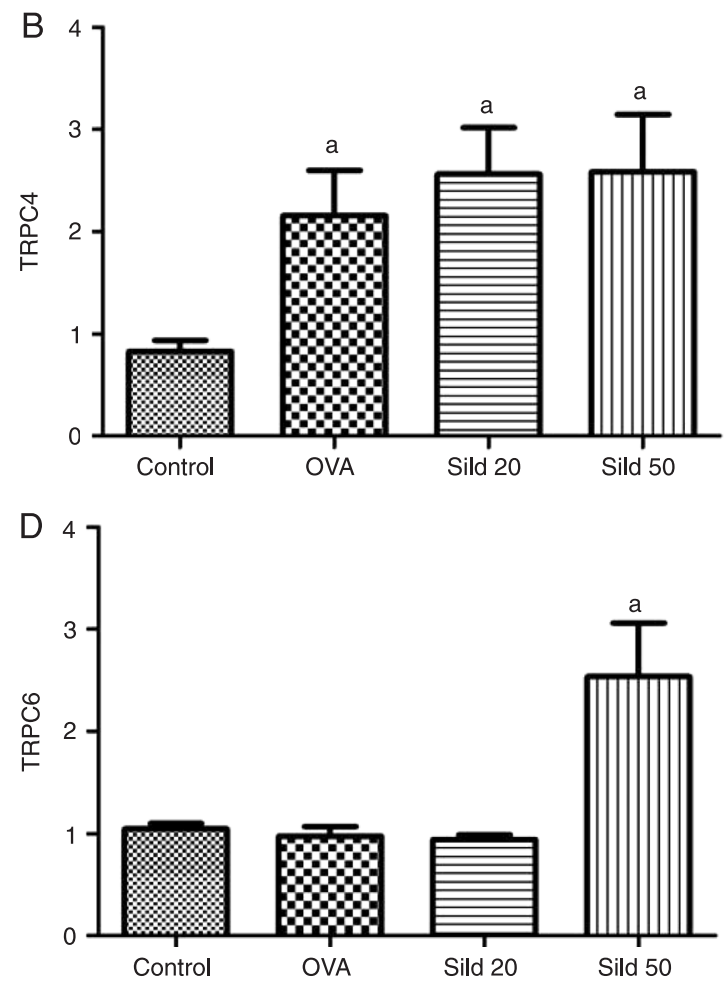

Figure 6. Relative expression of TRPC genes. The expression of the TRPC1, TRPC4, TRPC5, and TRPC6 genes was evaluated in samples of paries membranaceus of the rat trachea obtained from control and ovalbumin (OVA)-challenged animals that were treated or not with sildenafil ( 20 or $50 \mathrm{mg} / \mathrm{kg}$, ip; Sild 20 and Sild 50, respectively). Data are reported as means \pm SEM for 12 rats. aP $<0.05$ compared to control (Holm-Sidak test); ${ }^{b} \mathrm{P}<0.05$ compared to OVA (Holm-Sidak test). 
muscle cells of the rat bronchi (13) and guinea-pig trachea (33). Additionally, TRPC4 and TRPC6 were reported in myocytes isolated from human trachea (34). In the present study, in addition to these genes, the presence of TRPC5 mRNA was also detected. Although we cannot attribute the increased TRPC gene expression to a specific cell type because we used samples obtained from the entire wall of the rat trachea, it is reasonable to conclude that they play a functional role in the physiological behavior of rat airways, including smooth muscle cells. Antigen challenge with OVA increased the relative expression of both TRPC1 and TRPC4, suggesting a relationship between their gene activity and the development of antigen-induced inflammatory responses.

Recent evidence has demonstrated the putative significance of TRPC channels in the development of asthma, but the functional importance of these channels is still poorly understood (35). TRPC1 expression has been attributed to airway hyperresponsiveness, the thickening of airways, and bronchial remodeling induced by the proliferation of smooth muscle cells (36). The airways of TRPC6-/- mice showed increased responsiveness to methacholine both in vivo and in vitro. Their tracheal smooth muscle cells were more permeable to cation influx under basal conditions than smooth muscle cells of wild-type mice (27). These results show that, at least in mice, TRPC6 is important for determining airway contractile behavior.

In the present study, no modifications in TRPC5 or TRPC6 gene expression after antigen challenge with OVA were detected compared with control tissues, but after treatment with sildenafil, gene expression changed (i.e., the relative expression of TRPC5 decreased, whereas TRPC6 increased). Although control animals were not subjected to sildenafil treatment, such results imply an interaction between PDE5 and TRPC5 and TRPC6 genes in non-allergic conditions. Moreover, neither TRPC5 nor TRPC6 are likely to be involved in the development of tracheal hyperresponsiveness in rats. In contrast, although PDE5 inhibition further increased the relative expression of TRPC1, it did not appear to influence TRPC4 gene expression.

Another interesting result was the increased expression of TRPC6 induced by sildenafil treatment. TRPC6 proteins in vascular cells may suffer protein kinase Gmediated phosphorylation at threonine 69 , which strongly

\section{References}

1. Boolell M, Allen MJ, Ballard SA, Gepi-Attee S, Muirhead GJ, Naylor AM, et al. Sildenafil: an orally active type 5 cyclic GMP-specific phosphodiesterase inhibitor for the treatment of penile erectile dysfunction. Int J Impot Res 1996; 8: 4752.

2. Humbert M, Sitbon O, Simonneau G. Treatment of pulmonary arterial hypertension. N Engl J Med 2004; 351: 14251436. suppresses cation currents caused by TRPC6 expression (37). Although the extension of this phenomenon to the present inflammatory conditions sounds speculative, the inhibition of cGMP-selective PDE5 caused by sildenafil could also up-regulate TRPC6 expression in the rat trachea. The phosphorylation and functional suppression of TRPC6 induced by sildenafil has been previously reported to be an underlying mechanism involved in the prevention of pathological hypertrophy in mouse heart (38).

PDE5 inhibition in vascular tissues was associated with changes in the function of store-operated channels $(3,4)$. Sildenafil inhibited human pulmonary artery smooth muscle cell proliferation by decreasing capacitative $\mathrm{Ca}^{2+}$ entry, with its antiproliferative effect being partially related to the effect on calcium signaling via down-regulation of TRPC1 gene expression. Additionally, chronic hypoxia elevated basal intracellular $\mathrm{Ca}^{2+}$ levels in pulmonary artery smooth muscle cells by enhancing store-operated $\mathrm{Ca}^{2+}$ entry through probable up-regulated TRPC1 and TRPC6 gene expression (39). According to this study, sildenafil inhibited the increases in TRPC expression in cells exposed to prolonged hypoxia, and, as expected, it decreased TRPC 1 and TRPC6 expression to values found in control conditions.

Thus, considering that proteins of the TRPC subfamily constitute ion channels with permeability properties that vary from more $\mathrm{Ca}^{2+}$-selective channels, such as TRPC5 and TRPC6, to channels equally permeable for mono- and divalent cations, such as TRPC1 and TRPC4 (35), we hypothesize that the inflammatory environment elicited by antigen challenge modifies TRPC gene expression, and the PDE5 enzyme may be recruited in such a cascade of events. The putative involvement of the PDE5 pathway appears to be selective and to elicit activation or deactivation or is even inert in the cellular expression of a given TRPC gene. However, determining the functional relevance of this phenomena is not possible at this time and deserves further study to elucidate these interactions.

\section{Acknowledgments}

The authors would like to thank Mr. Michael Arends for assistance with the preparation of this manuscript. Research supported by CNPq via Edital Universal and INCT-IBISAB.
3. Wang C, Wang J, Zhao L, Wang Y, Liu J, Shi L, et al. Sildenafil inhibits human pulmonary artery smooth muscle cell proliferation by decreasing capacitative $\mathrm{Ca}^{2+}$ entry. $J$ Pharmacol Sci 2008; 108: 71-78.

4. Wang C, Li JF, Zhao L, Liu J, Wan J, Wang YX, et al. Inhibition of SOC/ $\mathrm{Ca}^{2+} / \mathrm{NFAT}$ pathway is involved in the antiproliferative effect of sildenafil on pulmonary artery smooth muscle cells. Respir Res 2009; 10: 123. 
5. Cosens DJ, Manning A. Abnormal electroretinogram from a Drosophila mutant. Nature 1969; 224: 285-287.

6. Montell C. Physiology, phylogeny, and functions of the TRP superfamily of cation channels. Sci STKE 2001; 2001: re1.

7. Smyth JT, Dehaven WI, Jones BF, Mercer JC, Trebak M, Vazquez G, et al. Emerging perspectives in store-operated $\mathrm{Ca}^{2+}$ entry: roles of Orai, Stim and TRP. Biochim Biophys Acta 2006; 1763: 1147-1160.

8. Trebak M. Canonical transient receptor potential channels in disease: targets for novel drug therapy? Drug Discov Today 2006; 11: 924-930.

9. Dietrich A, Chubanov V, Kalwa H, Rost BR, Gudermann T. Cation channels of the transient receptor potential superfamily: their role in physiological and pathophysiological processes of smooth muscle cells. Pharmacol Ther 2006; 112: 744-760.

10. Panettieri RA Jr, Kotlikoff MI, Gerthoffer WT, Hershenson MB, Woodruff PG, Hall IP, et al. Airway smooth muscle in bronchial tone, inflammation, and remodeling: basic knowledge to clinical relevance. Am J Respir Crit Care Med 2008; 177: 248-252.

11. Gelb AF, Zamel N, Krishnan A. Physiologic similarities and differences between asthma and chronic obstructive pulmonary disease. Curr Opin Pulm Med 2008; 14: 24-30.

12. Folkerts G, Nijkamp FP. Airway epithelium: more than just a barrier! Trends Pharmacol Sci 1998; 19: 334-341.

13. Sweeney M, McDaniel SS, Platoshyn O, Zhang S, Yu Y, Lapp BR, et al. Role of capacitative $\mathrm{Ca}^{2+}$ entry in bronchial contraction and remodeling. J Appl Physiol 2002; 92: 15941602.

14. Schultz WH. Physiological studies in anaphylaxis: 1. The reaction of smooth muscle of the guinea pig sensitized with horse serum. J Pharmacol Exp Ther 1910; 1: 549-567.

15. Dale $\mathrm{HH}$. The anaphylactic reaction of plain muscle in the guinea-pig. J Pharmacol Exp Ther 1913; 4: 167-223.

16. Brannan JD. Bronchial hyperresponsiveness in the assessment of asthma control: Airway hyperresponsiveness in asthma: its measurement and clinical significance. Chest 2010; 138: 11S-17S.

17. Pfaffl MW. A new mathematical model for relative quantification in real-time RT-PCR. Nucleic Acids Res 2001; 29: e45.

18. Buga GM, Gold ME, Wood KS, Chaudhuri G, Ignarro LJ. Endothelium-derived nitric oxide relaxes nonvascular smooth muscle. Eur J Pharmacol 1989; 161: 61-72.

19. Hashiba E, Sato T, Hirota K, Hashimoto Y, Matsuki A. The relaxant effect of propofol on guinea pig tracheal muscle is independent of airway epithelial function and beta-adrenoceptor activity. Anesth Analg 1999; 89: 191-196.

20. Nijkamp FP, van der Linde HJ, Folkerts G. Nitric oxide synthesis inhibitors induce airway hyperresponsiveness in the guinea pig in vivo and in vitro. Role of the epithelium. Am Rev Respir Dis 1993; 148: 727-734.

21. Fleischmann BK, Murray RK, Kotlikoff MI. Voltage window for sustained elevation of cytosolic calcium in smooth muscle cells. Proc Natl Acad Sci U S A 1994; 91: 11914-11918.

22. Toward TJ, Smith N, Broadley KJ. Effect of phosphodiesterase-5 inhibitor, sildenafil (Viagra), in animal models of airways disease. Am J Respir Crit Care Med 2004; 169: 227-234.

23. Al Qadi-Nassar B, Bichon-Laurent F, Portet K, Tramini P, Arnoux B, Michel A. Effects of L-arginine and phosphodiesterase -5 inhibitor, sildenafil, on inflammation and airway responsiveness of sensitized BP2 mice. Fundam Clin Pharmacol 2007; 21: 611-620.

24. Parekh AB, Penner R. Store depletion and calcium influx. Physiol Rev 1997; 77: 901-930.

25. Ito S, Kume H, Yamaki K, Katoh H, Honjo H, Kodama I, et al. Regulation of capacitative and noncapacitative receptoroperated $\mathrm{Ca}^{2+}$ entry by rho-kinase in tracheal smooth muscle. Am J Respir Cell Mol Biol 2002; 26: 491-498.

26. Lin L, Zheng C, Zhang L, Da C, Zhao K. Up-regulation of Orai1 in murine allergic rhinitis. Histochem Cell Biol 2010; 134: 93-102.

27. Sel S, Rost BR, Yildirim AO, Sel B, Kalwa H, Fehrenbach $H$, et al. Loss of classical transient receptor potential 6 channel reduces allergic airway response. Clin Exp Allergy 2008; 38: 1548-1558.

28. Xiao JH, Zheng YM, Liao B, Wang YX. Functional role of canonical transient receptor potential 1 and canonical transient receptor potential 3 in normal and asthmatic airway smooth muscle cells. Am J Respir Cell Mol Biol 2010; 43: 17-25.

29. Parekh AB, Putney JW Jr. Store-operated calcium channels. Physiol Rev 2005; 85: 757-810.

30. Gamberucci A, Giurisato E, Pizzo P, Tassi M, Giunti R, Mclntosh DP, et al. Diacylglycerol activates the influx of extracellular cations in T-lymphocytes independently of intracellular calcium-store depletion and possibly involving endogenous TRP6 gene products. Biochem J 2002; 364: 245-254.

31. Li S, Gosling M, Poll C. Determining the functional role of TRPC channels in primary cells. Pflugers Arch 2005; 451: 43-52.

32. Zhu X, Learoyd J, Butt S, Zhu L, Usatyuk PV, Natarajan V, et al. Regulation of eosinophil adhesion by lysophosphatidylcholine via a non-store-operated $\mathrm{Ca}^{2+}$ channel. Am J Respir Cell Mol Biol 2007; 36: 585-593.

33. Ong HL, Chen J, Chataway $\mathrm{T}$, Brereton $\mathrm{H}$, Zhang L, Downs $\mathrm{T}$, et al. Specific detection of the endogenous transient receptor potential (TRP)-1 protein in liver and airway smooth muscle cells using immunoprecipitation and Western-blot analysis. Biochem J 2002; 364: 641-648.

34. Corteling RL, Li S, Giddings J, Westwick J, Poll C, Hall IP. Expression of transient receptor potential $\mathrm{C} 6$ and related transient receptor potential family members in human airway smooth muscle and lung tissue. Am J Respir Cell Mol Biol 2004; 30: 145-154.

35. Colsoul B, Nilius B, Vennekens R. On the putative role of transient receptor potential cation channels in asthma. Clin Exp Allergy 2009; 39: 1456-1466.

36. Li S, Westwick J, Poll C. Transient receptor potential (TRP) channels as potential drug targets in respiratory disease. Cell Calcium 2003; 33: 551-558.

37. Takahashi S, Lin H, Geshi N, Mori Y, Kawarabayashi $\mathrm{Y}$, Takami N, et al. Nitric oxide-cGMP-protein kinase $\mathrm{G}$ pathway negatively regulates vascular transient receptor potential channel TRPC6. J Physiol 2008; 586: 4209-4223.

38. Nishida M, Watanabe K, Sato Y, Nakaya M, Kitajima N, Ide T, et al. Phosphorylation of TRPC6 channels at Thr69 is required for anti-hypertrophic effects of phosphodiesterase 5 inhibition. J Biol Chem 2010; 285: 13244-13253.

39. Lu W, Ran P, Zhang D, Peng G, Li B, Zhong N, et al. Sildenafil inhibits chronically hypoxic upregulation of canonical transient receptor potential expression in rat pulmonary arterial smooth muscle. Am J Physiol Cell Physiol 2010; 298: C114-C123. 